\title{
Autosomal Dominant Familial Neurohypophyseal Diabetes Insipidus Caused by a Novel Mutation in Arginine-Vasopressin Gene in a Brazilian Family
}

clinical case report

\author{
Maria EdNa de Melo \\ Suemi MaruI \\ VinícIus NAHIME DE BRITO \\ Marcio Corrêa MancinI \\ BERENICE B. MENDONCA \\ MiRTa KNOEPfelmacher
}

Unidade de Endocrinologia do Desenvolvimento, Laboratório de Hormônios e Genética Molecular/LIM42 da Disciplina de Endocrinologia e Metabologia do Hospital das

Clínicas da Faculdade de Medicina da Universidade de São Paulo, São Paulo, SP, Brasil.

Received in 25/8/2008 Accepeted in 14/10/2008

\section{ABSTRACT}

Autosomal dominant familial neurohypophyseal diabetes insipidus (adFNDI) is a rare autosomal dominant disorder characterized by polyuria and polydipsia due to deficiency of arginine vasopressin (AVP). More than 50 mutations causing adFNDI have been already reported in the AVP gene. The aim of the present study is to analyze the AVP gene in four generations of one Brazilian kindred with adFNDI. The proband was a 31-year old female with huge hypotonic polyuria ( $10 \mathrm{~L} /$ day) dated from childhood. Molecular analysis included amplification of all exons and exon-intron regions of the AVP gene by PCR and direct sequencing. Sequencing analysis showed a novel point mutation in heterozygous: G88V (GGC>GTC). All affected patients presented the same mutation also in heterozygous, while it was absent in four normal members. We expand the repertoire of mutations in AVP describing the novel G88V mutation in one Brazilian kindred with adFNDI. (Arq Bras Endocrinol Metab 2008; 52/8:1272-1276)

Keywords: Antidiuretic hormone; AVP; Familial diabetes insipidus; Argininevasopressin gene; Diabetes insipidus, neurogenic; Posterior pituitary gland

\section{RESUMO}

Diabetes Insípido Neuro-Hipofisário Familial Causado por uma Nova Mutação no Gene da Arginina-Vasopressina em uma Família Brasileira.

Diabetes insípido neuro-hipofisário com herança autossômica dominante (adFNDI) é uma doença autossômica dominante rara, caracterizada por poliúria e polidipsia devido à deficiência de arginina-vasopressina (AVP). Mais de 50 mutações causando adFNDI foram descritas no gene AVP. O objetivo deste estudo foi analisar o gene AVP em quatro gerações de uma família brasileira com DINF. O caso-índice é de uma paciente de 31 anos, com volumosa poliúria hipotônica desde a infância (10 L/dia). A análise molecular incluiu amplificação por PCR e seqüenciamento automático dos éxons e regiões éxon-íntron do gene AVP. A análise do seqüenciamento mostrou uma nova mutação de ponto em heterozigose: G88V (GGC>GTC). Todos os pacientes afetados apresentaram a mesma mutação, que não foi encontrada em quatro indivíduos normais da família. Expandimos a lista de mutações no gene AVP, descrevendo a nova mutação G88V em uma família brasileira com adFNDI. (Arq Bras Endocrinol Metab 2008; 52/8:1272-1276)

Descritores: Hormônio antidiurético; Diabetes insípido familiar; Gene AVP; Diabetes insípido neurogênico; AVP; Hipófise posterior

\section{INTRODUCTION}

amilial neurohypophyseal diabetes insipidus is a rare disorder characterized by polyuria and polydipsia due to arginine vasopressin (AVP) deficiency (1). This familial disorder generally occurs some months to years after 
birth, and ongoing progressive AVP deficiency has been described $(2,3)$.

The autosomal recessive inheritance was reported in one family but most patients present an autosomal dominant inheritance and more than 50 mutations, causing autosomal dominant familial neurohypophyseal diabetes insipidus, (adFNDI) have been already reported in AVP gene $(4,5)$. The AVP gene is located at chromosome $20(20 \mathrm{pl} 3)$ and encloses three exons: the first exon encodes a putative signal peptide, the AVP and the aminoterminal portion of neurophysin II (NPII); the second exon encodes the central portion of NPII; and the third exon encodes the carboxiterminal region of NPII and a glycoprotein, copeptin (6).

The NPII is the carrier protein of AVP and has been implicated in sorting the prohormone. The prohormone is synthesized in the magnocellular neurons of the supraoptic and paraventricular nuclei at hypothalamus and is subsequently transported into the nerve terminals in the neurohypophysis, via the regulated secretory pathway. In the secretory granules, processing of the vasopressin prohormone takes place, and upon stimulation of the nerve terminals processed products are released (7-9). Most AVP mutations are within NPII region and consist in substitutions of amino acids implicated in protein structure conformation, like cysteines involved in disulfide-bridge formation or prolines and glycines, which can make turns in polypeptide chains (10-12). Therefore, adFNDI represents the best known inherited endocrine disease caused by prohormone defects (3).

It has been proposed that the dominant negative effect of AVP mutations and the variability in onset of this disease, delayed to several months or years of age, are consequences of abnormal retention of abnormal prohormone in the endoplasmic reticulum, where it fails in folding and/or dimerizeing appropriately. This prolonged cytotoxic accumulation eventually leads to degeneration of neurons expressing mutant vasopressin prohormones (13).

In the current study, we present the molecular analyze of the AVP gene in a Brazilian pedigree. Eleven subjects were identified with the adFNDI, which spread for four generations, showing a complete penetrance.

\section{SUBJECTS AND METHODS}

We studied a Brazilian pedigree with adFNDI followed at our Institution. This study was approved by the Hos- pital Ethics Committee and written informed patient consent terms were obtained.

\section{Clinical evaluation}

The proband was a 31 year-old woman who presented clinical features of excessive polyuria and polydipsia. A water deprivation test (WDT) and a magnetic resonance image (MRI) of the hypothalamic-hypophyseal region were performed. Nine family members in four generations were supposed to be affected, judging from their symptoms (polyuria and polydipsia) (Figure 1).

\section{Molecular Analysis}

Genomic DNA was isolated from peripheral blood by standard methods from proband, thirteen relatives alive and a normal control.

\section{AVP gene PCR}

Three exons and exon-intron boundary regions of $A V P$ were individually amplified by PCR using intronic primers and protocol amplification as previously described (3). Masafumi buffer was essential to improve PCR reaction.

\section{Sequence analysis}

PCR products were treated with shrimp alkaline phosphatase and exonuclease I (PCR product pre-sequencing kit; Amersham Life Sciences Inc., Cleveland, Ohio, USA) prior to sequencing using the ABI PRISM BigDye Terminator kit (Perkin-Elmer Applied Biosystems, Foster City, California, USA). The products were then directly sequenced using an ABI PRISM 3100 Genetic Analyzer automatic DNA sequencer (Perkin-Elmer Applied Biosystems).

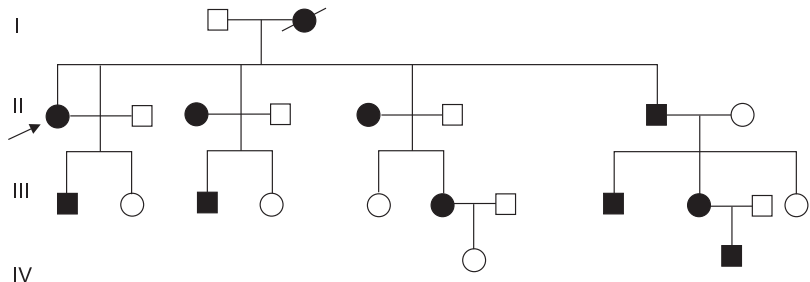

Figure 1. Pedigree of adFNDI. Black symbols indicate affected subjects; females are indicated by circles and males by squares. Subject indicated by the arrow was the proband. All affected individuals of II, III and IV generations and the normal individuals (III-2, III-5, III-7 and IV-1) were studied. The mutant allele was detected in all affected subjects. 


\section{Hpy188 III restriction assays}

The mutation G88V generates a restriction site for Hpy188 III enzyme. All relatives were screened for the G88V mutation, using $5 \mu \mathrm{l}$ of PCR product with $0.5 \mu \mathrm{l}$ of $H$ pyl 188 III enzyme ( $10 \mathrm{U} / \mu \mathrm{l})$ at temperature $37^{\circ} \mathrm{C}$, with inactivating at $65^{\circ} \mathrm{C}$. Mutant allele generates two fragments of 154 and 149-bp from PCR product.

\section{RESULTS}

\section{Clinical features}

The proband presented a characteristic response on WDT (plasma sodium levels enhanced from 146 to $149 \mathrm{mEq} / \mathrm{L}$; specific density changed from 1005 to 1007). MR image displayed an hypoplastic anterior pituitary and posterior pituitary was not visualized (Figure 2). The anterior pituitary function was evaluated by combined test and all pituitary hormonal responses were normal.

Proband relatives alive were three female and five male, with age ranged from 5 to $53($ mean $=32.5)$. The mean chronological age onset of symptoms in five patients was $4.36 \mathrm{yr}$ (ranging from 4 months to 11 years). In the other patients the precise age onset of symptoms could not be determined, mainly because they did not recognize the huge amount of water intake as anomalous, since many relatives used to drink the same. In most patients the diagnosis was achieved after the family screening evaluation.

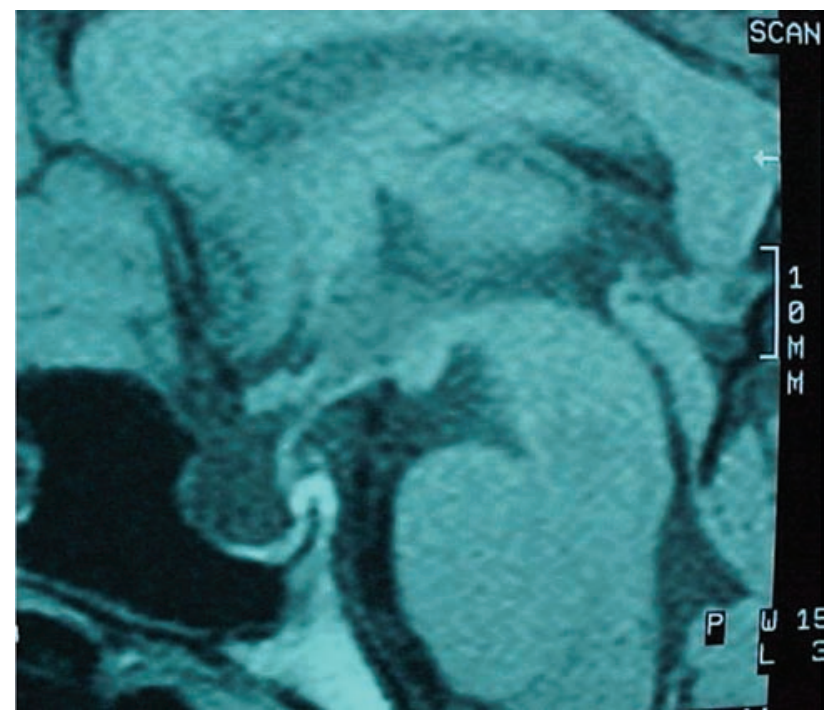

Figure 2. Sagital view of MRI showing a hypoplastic anterior pituitary and posterior pituitary not visualized.

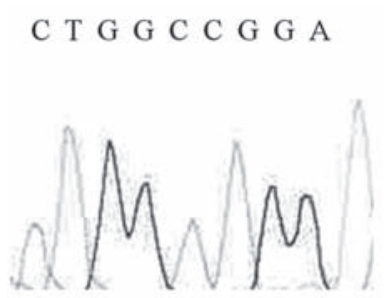

A

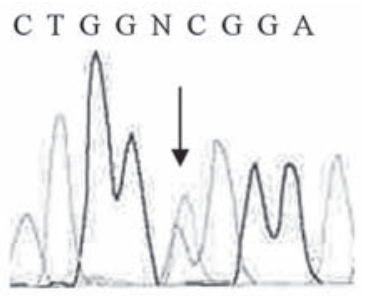

B
Figure 3. Direct sequencing analysis of part of exon 2 using reverse primer from normal $(A)$ and from one patient with adFNDI (B). The arrow indicates the mutation in heterozygous state, demonstrating the novel G88V mutation in AVP gene.

The adFNDI phenotype in this pedigree displayed an autosomal dominant mode of inheritance (Figure 1).

\section{Molecular results}

Sequencing analysis showed a novel point mutation in heterozygous state in exon 2. The nucleotide 1859 takes part in codon 88 (GGC>GTC) and this substitution results in an amino acid substitution of glycine to valine (G88V) (Figure 2). This codon encodes the glycine in position 57 of neurophysin - NP57.

The screening of this novel mutation was performed in all alive relatives using the restriction enzyme Hpyl88 III confirming the same mutation in all other nine affected members, while it was absent in 4 normal members and a normal control.

\section{DISCUSSION}

In this report, we studied a large family with clinical, laboratorial and molecular diagnosis of adFNDI. The proband patient presented a huge polyuria which motivated him to search medical help. The fluid deprivation test was characteristic of AVP deficiency as well as the absence of the hyper signal in the posterior pituitary. Family adjustment to polyuria and, consequently, polydipsia is an interesting finding in these cases and can be associated to progressive establishment of disease, which is corroborated by previous reports on gradual decline in vasopressin secretion (2). Most of the relatives have not realized that they had polydipsia because this was the familiar pattern of water ingestion, and they were studied only after the proband was investigated in our Service.

Sometimes it is possible that patients can present a suggestive history of DI associated to a inconclusive WDT. 
For them, the measurement of AVP and molecular analysis of $A V P$ is crucial for the diagnosis of DI (15).

Abnormalities in the pituitary are described in the MRI of patients with adFNDI, such as absence of posterior pituitary bright spot (15). Our patient presented a hypoplastic anterior pituitary on MRI and this finding did not correlate with clinical and laboratorial evaluation, revealed as normal. The cause of this structural abnormality is still unclear, and emphasizes the importance to monitor the anterior pituitary function in this patient.

Some technical difficulties in PCR amplification and direct sequencing of AVP were encountered because this gene is extremely rich in $\mathrm{G}+\mathrm{C}$, especially in the last half of the gene where these nucleotides encompass more than $70 \%$ of the sequence, as already reported by other researchers (3).

In the present study, we have identified a novel point mutation in AVP gene (G88V). This is the third mutation described in codon 88 that encodes one glycine (16). Two different mutations in the same codon (G88S and G88R) have been already described in patients with a similar phenotype. Glycine in codon 88 displays full interspecies conservation (6). In addition, glycine and valine are both amino acids non polar and neutral, otherwise, valine is more than ten times more hydrophobic than glycine (17).

Nijenhuis and cols. performed functional analyses of five mutations in the AVP gene, three of them in glycine residues (G45R, G96V and G88S, respectively NP14G, NP65G and NP57G positions on neurophy$\sin )$. The analyzes of mutation G88S displayed a relatively efficient processing and secretion of protein, an aberrant distribution of the mutant prohormone within the endoplasmic reticulum (ER) and a modification in ER distribution in cells (13). Therefore, they propose that the accretion and the consequent disturbance of the ER are deleterious to the cell and will decrease the functionality and/or the viability of the magnocellular neurons, which express high amounts of vasopressin prohormone in vivo (13). This hypothesis would explain both the dominant inheritance of human adFNDI and the delayed onset of the symptoms, as observed in some patients here described.

Another study showed that mutation of residues NP14G or NP65G, which are both located in one of the $\beta$-pleated sheet of the NPII, virtually abolished efflux of phrohormone from the ER (18). Mutation of residue NP57, which is located in the loop connecting the $\alpha$-helix with the $\mathrm{C}$-terminal $\beta$-pleated sheet of NPII, provokes only a decrease in the efflux of prohormone (19). The grade of severity of ER retention for different vasopressin prohormones suggests that mutations in the $\beta$-strands of neurophysin are most deleterious for folding of the vasopressin prohormone, followed by mutations in the $\alpha$-helix and then by mutations in less ordered structures like the loop from residues 50-58 (19). These findings were reinforced by analyzes in vitro performed by Eubansks and cols. (20) demonstrating that the mutation G88S has weaker free energy of internal bonding between hormone and NPII than in the WT precursor.

One important practical issue to detect AVP mutation and confirm the diagnosis of adFNDI is to be able to predict the development of adFNDI in asymptomatic members, since the penetrance of this disease appears to be $100 \%(15)$.

In conclusion, we expanded the repertoire of $\mathrm{mu}^{-}$ tations in AVP describing the novel G88V mutation in one Brazilian kindred with adFNDI.

No potential conflict of interest relevant to this article was reported.

\section{REFERENCE}

1. Knoepfelmacher M, Melo ME. Diabetes Insipidus e Síndrome da Secreção Inapropriada de Hormônio Antidiurético. In: Endocrinologia Para o Pediatra. 3rd Ed. São Paulo: Atheneu; 2006.p.597-616.

2. Elias PC, Elias LL, Torres N, Moreira AC, Antunes-Rodrigues $\mathrm{J}$, Castro M. Progressive decline of vasopressin secretion in familial autosomal dominant neurohypophyseal diabetes insipidus presenting a novel mutation in the vasopressin-neurophysin II gene. Clin Endocrinol (Oxf) 2003; 59(4):511-8.

3. Ito $\mathrm{M}$, Mori $\mathrm{Y}$, Oiso $\mathrm{Y}$, Saito $\mathrm{H}$. A single base substitution in the coding region for neurophysin II associated with familial central diabetes insipidus. J Clin Invest. 1991;87(2):725-8.

4. Willcuts MD, Felner E, Whight PC. Autosomal recessive familial neurohypophyseal diabetes insipidus with ontinued secretion of mutant weakly active vasopressin. Hum Mol Genet. 1999;8(7) 1303-7.

5. Baglioni S, Corona G, Maggi M, Serio M, Peri A. Identification of a novel mutation in the arginine vasopressin-neurophysin II gene affecting the sixth intrachain disulfide bridge of the neurophysin II moiety. Eur J Endocrinol. 2004;151 605-11.

6. Brownstein MJ, Russell JT, Gainer H. Synthesis, transport, and release of posterior pituitary hormones. Science. 1980;207(4429):373-8.

7. de Bree FM, Burbach JP. Structure-function relationships of the vasopressin prohormone domains. Cell Mol Neurobiol. 1998;18(2):173-91. 
8. Arvan P, Castle D. Sorting and storage during secretory granule biogenesis: looking backward and looking forward. Biochem J. 1998; 332: 593-610.

9. Burgoyne RD, Morgan A. Regulated exocytosis. Biochem J. 1993;293:305-16.

10. Ueta Y, Taniguchi S, Yoshida A, Murakami I, Mitani Y, Hisatome I, et al. A new type of familial central diabetes insipidus caused by a single base substitution in the neurophysin II coding region of the vasopressin gene. J Clin Endocrinol Metab. 1996; 81(5):1787-90.

11. Gagliardi PC, Bernasconi S, Repaske DR. Autosomal dominant neurohypophyseal diabetes insipidus associated with a missense mutation encoding Gly23-->Val in neurophysin II. J Clin Endocrinol Metab. 1997;82(11):3643-6.

12. Grant FD, Ahmadi A, Hosley CM, Majzoub JA. Two novel mutations of the vasopressin gene associated with familial diabetes insipidus and identification of an asymptomatic carrier infant. J Clin Endocrinol Metab. 1998;83(11):3958-64.

13. Nijenhuis M, Zalm R, Burbach JP. Mutations in the vasopressin prohormone involved in diabetes insipidus impair endoplasmic reticulum export but not sorting. J Biol Chem. 1999; 274(30):21200-8.

14. Miller AS, Dykes DD, Polesky HF. A simple salting out procedure for extracting DNA from human nucleated cells. Nucleic Acids Res. 1988;16:1215.

15. Chirutti S, Harris M, Thomsett MJ, Bowling F, McGown I, Cowley D, Leong GM, Batch J, Cotterill AM. Utility of AVP gene testing in familial neurohypophyseal diabetes insipidus. Clin Endocrinol (Oxf). 2008 May 20. [Epub ahead of print].
16. Rittig S, Robertson GL, Siggaard C, Kovács L, Gregersen N, Nyborg J, Pedersen EB. Identification of 13 new mutations in the vasopressin-neurophysin II gene in 17 kindreds with familial autosomal dominant neurohypophyseal diabetes insipidus. Am J Hum Genet. 1996;58(1):107-17.

17. Nelson DL, Cox MM. Lehninger Principles of Biochemistry. 4th Ed. New York: W.H.Freeman.; 2004.

18. Olias G, Richter D, Schmale H. Heterologous expression of human vasopressin-neurophysin precursors in a pituitary cell line: defective transport of a mutant protein from patients with familial diabetes insipidus. DNA Cell Biol. 1996;15(11):929-35.

19. Ito M, Jameson JL, Ito M. Molecular basis of autosomal dominant neurohypophyseal diabetes insipidus. Cellular toxicity caused by the accumulation of mutant vasopressin precursors within the endoplasmic reticulum. J Clin Invest. 1997;99(8): 1897-905.

20. Eubanks S, Nguyen TL, Deeb R, Villafania A, Alfadhli A, Breslow $E$. Effects of diabetes insipidus mutations on neurophysin folding and function. J Biol Chem. 2001;276(32):29671-80.

\section{Endereço para correspondência:}

Maria Edna de Melo

Hospital das Clinicas da FMUSP

Rua Dr Enéas de Carvalho Aguiar, 255-2 andar Bloco 6 , 05403-900, São Paulo, SP

E-mail: medna@usp.br 